\title{
Age and growth of two sympatric squid Loligo vulgaris and Loligo forbesi, in Galician waters (north-west Spain)
}

\author{
F. Rocha and A. Guerra \\ Instituto de Investigaciones Marinas (CSIG), Eduardo Cabello 6, 36208 Vigo, Spain
}

\begin{abstract}
Age and growth of Loligo vulgaris and L. forbesi were studied by the examination of growth increments in 96 and 135 selected (white zone <10\%) statoliths, respectively. Squid were obtained by monthly sampling from the catches of commercial trawling and hand-jigs in Galician waters (north-west Spain) between February 1991 and October 1993. Mantle length (ML) of L. vulgaris ranged from 70 to $480 \mathrm{~mm}$ and varied between 70 and $685 \mathrm{~mm}$ in L. forbesi. A negative allometry between statolith length and ML or body weight (BW) was found in both species. Sexual dimorphism was apparent in both species, males grew faster and longer than females. The statolith analysis suggests that growth patterns of $L$. vulgaris and L. forbesi in Galician waters are different. The exploited population of L. vulgaris was composed of two groups: one formed by individuals hatched in winter-spring and another by specimens hatched in summer-autumn. Squid hatched in winter-spring reached larger sizes at the same age than those hatched in summer-autumn. These two groups were also observed in L. forbesi. However, squid of this species hatched in winter-spring were smaller than those hatched in summer-autumn at the same age. Reasons for this discrepancy are discussed. The life span of L. vulgaris was about one year whereas the life span of L. forbesi extended to 18 months.
\end{abstract}

\section{INTRODUCTION}

The loliginid squid Loligo vulgaris Lamarck, 1798 and Loligo forbesi Steenstrup, 1856 constitute one of the most important cephalopod fishery resources of Europe and West Africa. A total of 15,000 tonnes and 3,000 tonnes of both species, respectively, were caught during 1995 in these areas (FAO, 1997). Knowledge of the demographic structure of populations permits the evaluation of population biomass changes caused by natural or fishing mortality. This information implies a precise study of the age and growth of individuals. Furthermore, it is important to study the age and growth of cephalopods since knowledge of these parameters makes it possible to compare different maturation, feeding and ecological patterns of a species during its life cycle (Bettencourt et al., 1996).

Cephalopod statoliths show growth increments and their use in age estimations is becoming established. It has been validated that growth increments are deposited daily in several species (for a review see Jackson, 1994). This opens up the possibility of using age-based assessment even if age cannot be reliably estimated from length as in the case of cephalopods (Pierce \& Guerra, 1994)

Published information on the age and growth of L. vulgaris using statoliths are based on specimens from the north-west Mediterranean (Natsukari \& Komine, 1992), north-west Spain (Guerra \& Rocha, 1994), the West Saharan Shelf (Arkhipkin, 1995) and the south of Portugal (Bettencourt et al., 1996). These studies have shown that growth rates varied considerably among individuals. Double exponential, Gompertz and Power functions, were used to describe growth of the species. And finally, all these studies concluded that the life span of $L$. vulgaris is about one year.
Statolith studies of $L$. forbesi are basically restricted to investigation by Collins et al. (1995a) in Irish waters. Preliminary results by Martins (1982) examining only 40 statoliths of specimens from the Azores showed ages of 7-8 months for $310 \mathrm{~mm}$ of mantle length (ML) in females and 15 months for $740 \mathrm{~mm}$ ML in males. Collins et al. (1995a) provided indirect evidence of the daily deposition of growth increments in the statolith of this species. Growth data were fitted to a logarithmic function and it was shown than males grew faster and attained larger sizes than females. Collins et al. (1995a) also indicated a one year life span for this species whilst Guerra \& Rocha (1994) estimated a life span of 16 months.

Studies by Natsukari \& Komine (1992), Arkhipkin (1995), Collins et al. (1995a) and Bettencourt et al. (1996) found a great growth and age variability between specimens of the same size. Thus, squid of the same size showed that the increments counted in prepared statoliths ranged between 80 and 150 and from 60 to 200 in L. vulgaris and L. forbesi, respectively.

Moreover, comparisons between ageing results of these studies are difficult because they are based on specimens from different fishing grounds and they were carried out by different authors using different methodologies. It is well known that cephalopod growth is influenced markedly by biotic and abiotic factors (Forsythe \& Van Heukelem, 1987; Forsythe, 1993), and that errors between readers and due to differences in methodologies are considerable when counting increments (González, et al., 1998). To date, ageing studies based on both species from the same fishing ground, except for some preliminary observations by Guerra \& Rocha (1994), have not been achieved.

The aim of the present study was to evaluate age and growth of both species from the same fishery area, and to 


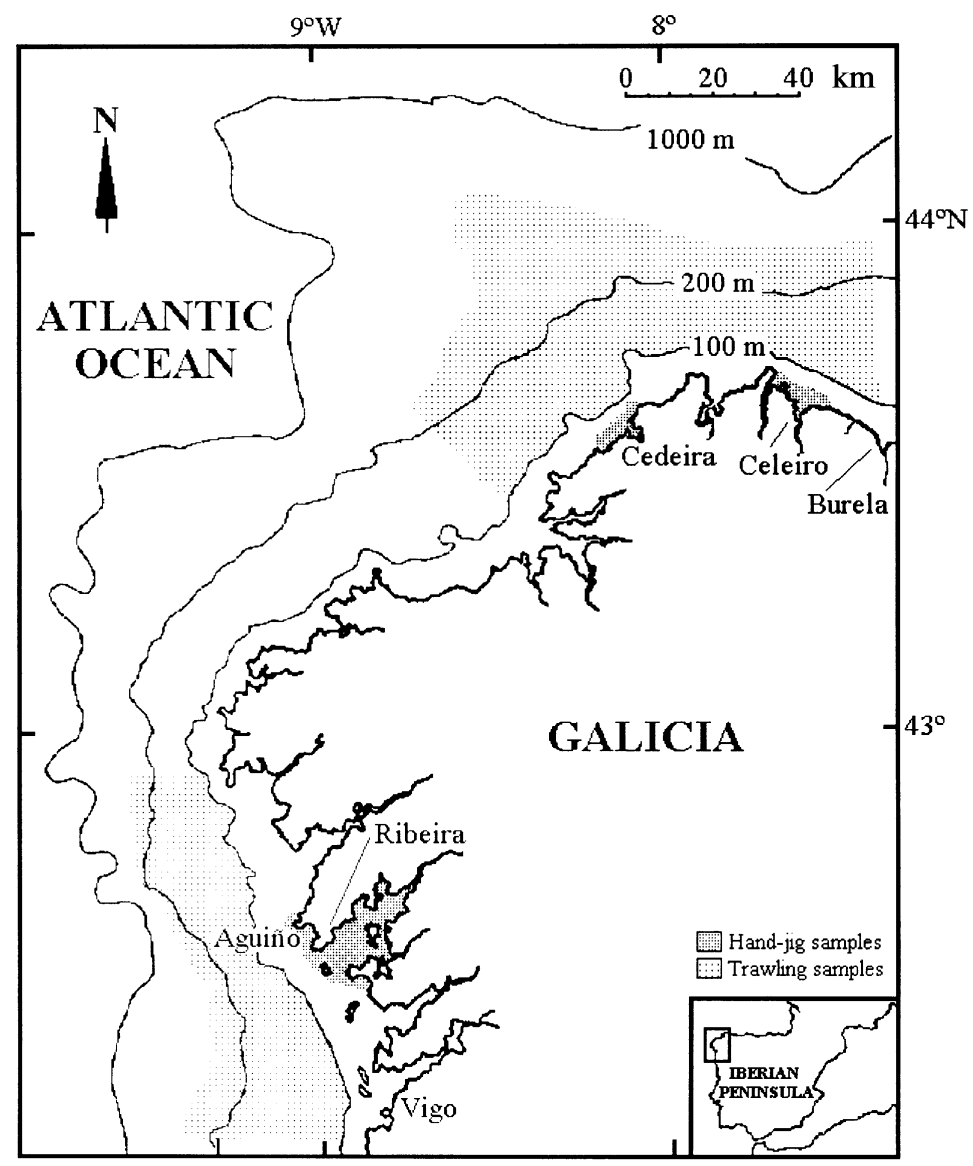

Figure 1. Loligo vulgaris and L. forbesi. Map of the Galician coast (north-west Spain) showing the sampling ports and the fishing grounds where trawl and hand-jig samples were collected.

compare estimates obtained by the same researcher using the same methodology.

\section{MATERIAL AND METHODS}

\section{Statolith sampling}

From February 1991 to October 1993 samples of commercially caught squid Loligo vulgaris and L. forbesi were collected at fish markets from the Galician (northwest Spain) fishing ports of Cedeira, Celeiro, Burela, Aguiño and Ribeira (Figure 1). Monthly samples were obtained from both trawling and hand jig fisheries. These squid species are caught as a by-catch in the multi-species trawler fishery. Depths where trawlers operate range from 100 to $400 \mathrm{~m}$. Trawl mesh size is $60 \mathrm{~mm}$ in the codend. Both species are caught by a direct small-scale hand-jig fishery at depths of between 4 and $40 \mathrm{~m}$. This artisanal fishery was described by Simón et al., (1996). Allozyme electrophoretic analysis has shown that animals caught in both fisheries belong to the same populations (PérezLosada, 1998). After sorting according to species a random representative sample was taken of the total landing.

A total of 1828 L. vulgaris (41 unsexed, 862 males and 925 females) and 792 L. forbesi (31 unsexed, 399 males and 356 females) were sampled. An average number of 55 specimens of $L$. vulgaris and 24 specimens of $L$. forbes $i$ were obtained in each sample, and taken to the laboratory in $0^{\circ} \mathrm{C}$ ice-boxes and then frozen at $-30^{\circ} \mathrm{C}$. The dorsal mantle length (ML in $\mathrm{mm}$ ) and wet body weight (BW in $g$ ) of each thawed specimen was noted after defrosting at room temperature, sex was determined and a maturity stage assigned (Boyle \& Ngoile, 1993). Sizes of the individuals sampled ranged from $70-480 \mathrm{~mm} \mathrm{ML}$ and 67-685 mm ML, respectively.

A total of 269 L. vulgaris statoliths (2 unsexed, 127 males and 140 females) and 278 L. forbesi statoliths (18 unsexed, 144 males and 116 females) were taken from squid with ML ranging from $70-480 \mathrm{~mm}$ and $67-685 \mathrm{~mm}$, respectively. Statoliths were removed (Arkhipkin, 1991) and stored in $99.5 \%$ ethyl alcohol.

\section{Statolith preparation and increment counts}

All statoliths were measured (to $0.01 \mathrm{~mm}$ ) from the end of the dorsal dome to the rostrum tip (statolith length, $\mathrm{SL})$, using a dissecting microscope $(\times 15)$ fitted with an eyepiece micrometer. Statoliths were prepared as described by Arkhipkin (1991) and Villanueva (1992). The statoliths were mounted in Pro-texx resin, ground and polished on both sides using 3M commercial waterproof sandpaper, coarse $(30 \mu \mathrm{m})$ and fine grain $(1 \mu \mathrm{m})$, respectively. Statolith terminology follows that of Clarke (1978).

Growth increments were counted using an Image Analysis System comprised of a light microscope 


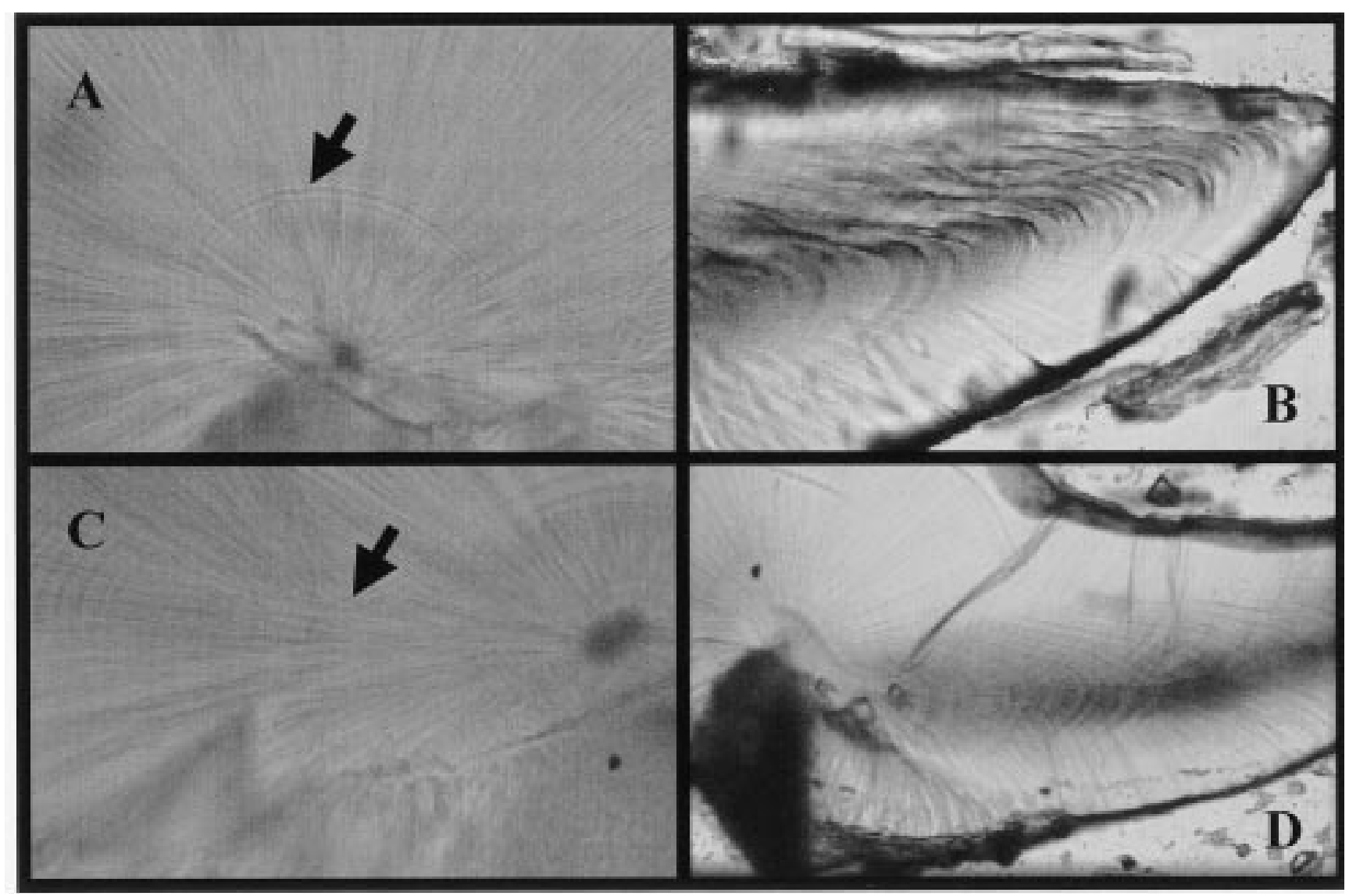

Figure 2. Loligo vulgaris and L. forbesi. Photomicrograph of ground statoliths and increments: (A) L. vulgaris, nucleus and natal ring; (B) L. vulgaris, tip of the rostrum; (C) L. forbesi, nucleus and natal ring; (D) L. forbesi, rostrum.

OPTIPHOT-2 (40 objective) with a video output to a high resolution colour monitor connected to a computer and photographic printer. The software package used was VIDS (Video Image Digital Software). Increments were counted by hand on the TV monitor screen $(\times 700 \mathrm{dpi})$. An increment was defined as the bipartite structure within the statolith composed of a dark and light ring (Lipinski et al., 1991; Jackson, 1994). Growth increments were counted from the natal ring to the end of the rostrum (Natsukari et al., 1988). The total number of increments (NI) in each statolith was counted, and the distance along the statolith where the increments were not visible (white zone or obliterate zone, whose location varies) was measured. Statoliths with more than $10 \%$ of white zone were rejected. Increments in the white zone were estimated by interpolation. The consistency of statolith-increment counting was tested by obtaining two replicate counts by the same reader for 17 statoliths of each species which yielded coefficients of variations of $0.7-2.2 \%$. Therefore, accumulative effects of counting error by the same reader were judged to be negligible. The validity of the ageing technique used in this work and semi-automatic increment counts were demonstrated by González et al. (1988) re-analysing a set of previously analysed known-age Sepioteuthis lessoniana statoliths.

Growth increments were validated to be daily in L. forbesi by Hanlon et al., (1989), assuming that increments were also deposited daily in $L$. vulgaris. The hatching date of each specimen was estimated by backcalculation from date of capture and increment counts.
The relationships between mantle length (ML), body weight (BW) and statolith length (SL) were estimated considering sexes separately. Gompertz, exponential, power and logarithmic curve growths were tested. Differences of slopes and elevations in the relationships SL-ML and SL-BW between sexes were compared using Student's test (Zar, 1984) with variables logarithmically transformed.

\section{Growth rate estimations}

Daily growth rates (DGR $\mathrm{mm} \mathrm{d}^{-1}$ ) and instantaneous daily growth rate, $\mathrm{G}$, were calculated using the equations given by Forsythe \& Van Heukelem (1987):

$$
\begin{aligned}
& \operatorname{DGR}=\frac{\left(\mathrm{W}_{2}-\mathrm{W}_{1}\right)}{\left(\mathrm{T}_{2}-\mathrm{T}_{1}\right)} \\
& \mathrm{G}=\left(\frac{\left(\ln \mathrm{W}_{2}-\ln \mathrm{W}_{1}\right)}{\left(\mathrm{T}_{2}-\mathrm{T}_{1}\right)}\right) \times 100
\end{aligned}
$$

where $\mathrm{W}_{1}$ and $\mathrm{W}_{2}$ are ML (mm) at the beginning and the end of the time interval $\mathrm{T}_{2}-\mathrm{T}_{1}$.

Growth equations obtained were logarithmically transformed and their slopes and elevations compared using Student's test (Zar, 1984). 
Table 1. Loligo vulgaris and $\mathrm{L}$. forbesi relationships between statolith length $(S L)$; mantle length in $\mathrm{mm}(M L)$ and body weight in $g(B W)$.

\begin{tabular}{llcccc}
\hline Relationship & Sex & $\mathrm{a}$ & $\mathrm{b}$ & $r^{2}$ & $\mathrm{~N}$ \\
\hline Loligo vulgaris & & & & & \\
SL-ML & Males & 0.3358 & 0.3045 & 0.75 & 127 \\
& Females & 0.3242 & 0.3174 & 0.68 & 140 \\
SL-BW & Males & 0.8582 & 0.1280 & 0.76 & 123 \\
& Females & 0.8423 & 0.1346 & 0.71 & 133 \\
Loligoforbesi & & & & & \\
SL-ML & Males & 0.4892 & 0.2692 & 0.89 & 132 \\
& Females & 0.4257 & 0.2996 & 0.83 & 105 \\
SL-MW & Males & 1.1275 & 0.1100 & 0.88 & 130 \\
& Females & 1.1078 & 0.1164 & 0.84 & 103 \\
\hline
\end{tabular}

Intercept (a), slope (b), coefficient of determination $\left(r^{2}\right)$ and number of statoliths $(\mathrm{N})$ are indicated for the power equation $\left(\mathrm{SL}=\mathrm{a}(\mathrm{ML})^{\mathrm{b}}\right)$.

\section{RESULTS}

Statolith microstructure

Each growth increment in the statolith of both species comprises two components, one optically translucent (light) layer and another opaque (dark) layer (Figure 2). This opaque layer will be called a 'ring'. The nucleus appears as an opaque droplet-like area in both species. Several tiny primordia appear as small, dark concretions, which are more densely distributed inwards. Careful observations showed that faint increments were partially visible in the nucleus. Those increments were probably formed during the embryonic development.

The natal ring, which is formed at hatching, was observed as an especially prominent opaque dark layer. This was the starting point for counting increments to estimate age in days after hatching in both loliginid species.

In the present study increments were observed in two ways: from the natal ring to the rostrum and from the natal ring to the dorsal dome. However, the increments were more clearly visible in the first case. This was the reason why the increments were counted from the natal ring to the rostrum in both species. Moreover, two types of rings were recognized in prepared statoliths: fine, relatively light, uniformly spaced rings, and thick, dark rings.

\section{Growth of the statolith}

The relationship between statolith length (SL) and mantle length (ML) and body weight (BW) in both species (excluding unsexed animals) was best described by a power equation (Table 1). In both species and sexes, power (allometric) slope was $<1$, revealing negative allometry between statolith growth and ML or BW. No significant differences $(P>0.05)$ were found in SL-ML and SL-BW relationships between L. vulgaris males and females (Table 2). The power equations fitted for the SLML relationship showed no significant differences $(P>0.05)$ between $L$. forbesi males and females. However, differences between the slope of the male and female SL-BW equations were statistically significant $(P<0.05)$ in L. forbesi (Table 2).

\section{Age and growth of squid}

The youngest squid had a total of 167 increments (female of $92 \mathrm{~mm} \mathrm{ML}$ ) and 119 increments (unsexed of $67 \mathrm{~mm} \mathrm{ML}$ ) in L. vulgaris and L. forbesi, respectively. The maximum number of increments for females was 361 increments (255 $\mathrm{mm} \mathrm{ML}$ ) and 382 increments (383 $\mathrm{mm} \mathrm{ML)}$ for males of $L$. vulgaris. In the case of $L$. forbesi, the maximum number of increments for females was 514 increments (322 $\mathrm{mm} \mathrm{ML})$ and 480 increments (400 $\mathrm{mm} \mathrm{ML)}$ for males.

Assuming that increments were deposited daily, hatching dates were back calculated from date of capture and increment counts (Figure 3). The distributions of hatching dates by sex between September 1990 and October 1991 are illustrated in Figure 4. Hatching occurred throughout the year in both species, although most hatching occurred in winter, spring and summer.

Loligo vulgaris

The $64 \%$ of the prepared statoliths were rejected because they had more than $10 \%$ of white zone. A total of 96 statoliths (43 males and 53 females) were used for age estimations.

Figure 5 shows the relationship between the statolith length (SL) and the number of increments (NI) in males and females.

Figure 6 illustrates the relationship between NI and ML of males and females hatched between December 1990-July 1991.

Table 2. Loligo vulgaris and L. forbesi comparisons between males and females of the equations (slope and intercept) given in Table 1 for relationships SL vs $M L$ and SL vs BW using Student's test.

\begin{tabular}{|c|c|c|c|c|c|c|c|c|}
\hline \multirow{2}{*}{$\frac{\text { Comparison }}{\text { Males vs Females }}$} & \multicolumn{4}{|c|}{ Slope } & \multicolumn{4}{|c|}{ Intercept } \\
\hline & $t$ & $v$ & $P$ & Prob. & $t$ & $v$ & $P$ & Prob. \\
\hline \multicolumn{9}{|l|}{ Loligo vulgaris } \\
\hline $\mathrm{SL}-\mathrm{ML}$ & 0.2308 & 15 & $P>0.05$ & ns & 0.2324 & 16 & $P>0.05$ & ns \\
\hline SL-BW & 1.1944 & 12 & $P>0.05$ & ns & 1.1190 & 13 & $P>0.05$ & $\mathrm{~ns}$ \\
\hline \multicolumn{9}{|l|}{ Loligo forbesi } \\
\hline SL-ML & 0.8126 & 22 & $P>0.05$ & ns & 0.7579 & 23 & $P>0.05$ & ns \\
\hline SL-BW & 2.1321 & 22 & $P<0.05$ & $*$ & 1.8548 & 23 & $P>0.05$ & ns \\
\hline
\end{tabular}

Prob., level of probability; *, significant differences; ns, no significant differences. 

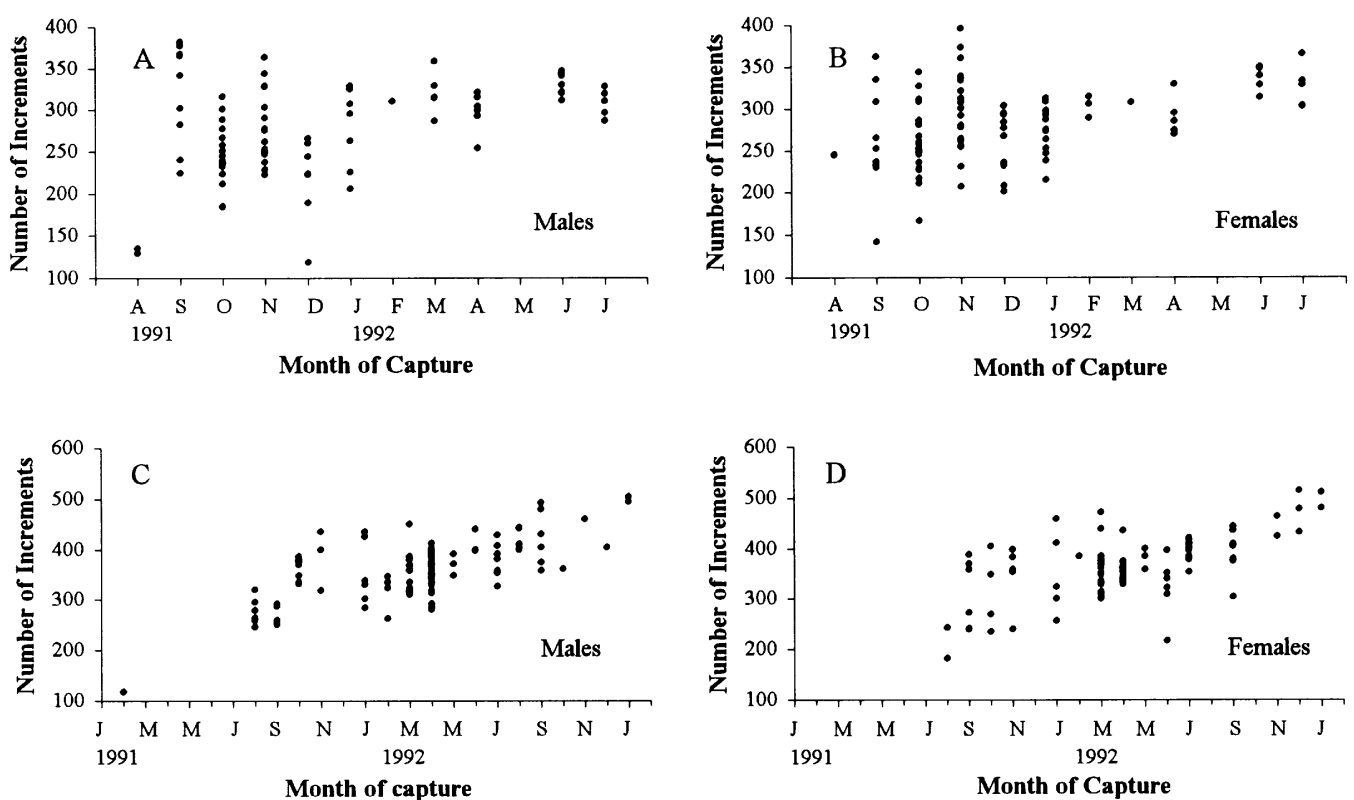

Figure 3. Loligo vulgaris and L. forbesi. Relationship between number of increments counts and date of capture. (A) Loligo vulgaris males; (B) Loligo vulgaris females; (C) L. forbesi males; (D) L. forbesi females.

Data analysis showed that statolith increment values for males and females can be separated into two groups, according to hatching dates: summer-autumn and winter-spring groups (Figure 6). The best growth curve that fitted the data for both sexes and groups was an exponential function. Parameters of these exponential functions as well as daily growth rate (DGR) and instantaneous daily growth rate $(G)$ values for males and females of both groups are shown in Table 3 .

The post-hatch life span of males and females of the species should be about one year or less because it would be possible to reach the maximal ML recorded $(480 \mathrm{~mm}$ for males and $350 \mathrm{~mm}$ for females) within one year with the estimated growth rates.
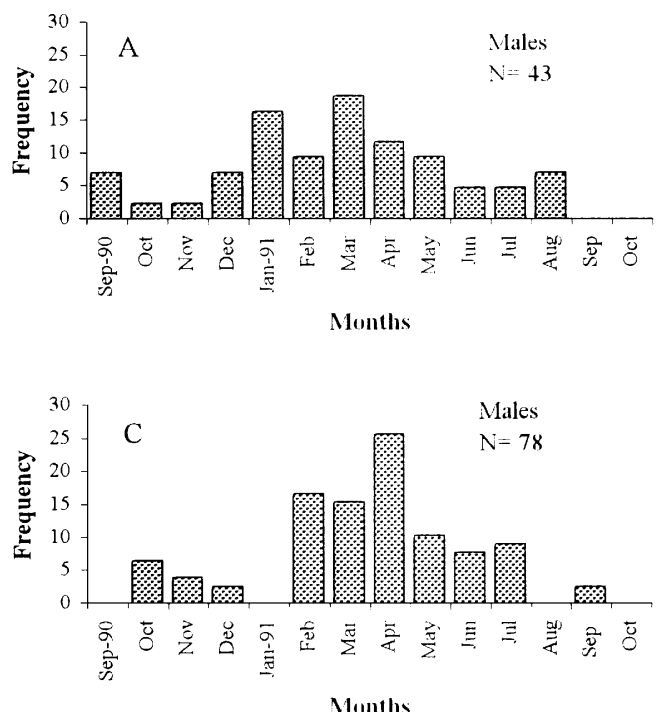

Males and females of this species showed a significantly different growth rate (Table 4), males grew faster than females. However, no significant differences $(P>0.05)$ were found in the growth rate of specimens of the same sex hatched in summer-autumn or winter-spring (Table 4).

\section{Loligo forbesi}

The $51 \%$ of the prepared statoliths were rejected because they had more than $10 \%$ of white zone. A total of 135 statoliths (78 males and 57 females) were used for age estimations.

A relatively high individual variation in statolith length (SL) vs number of increments (NI) in males and females is apparent from Figure 7.
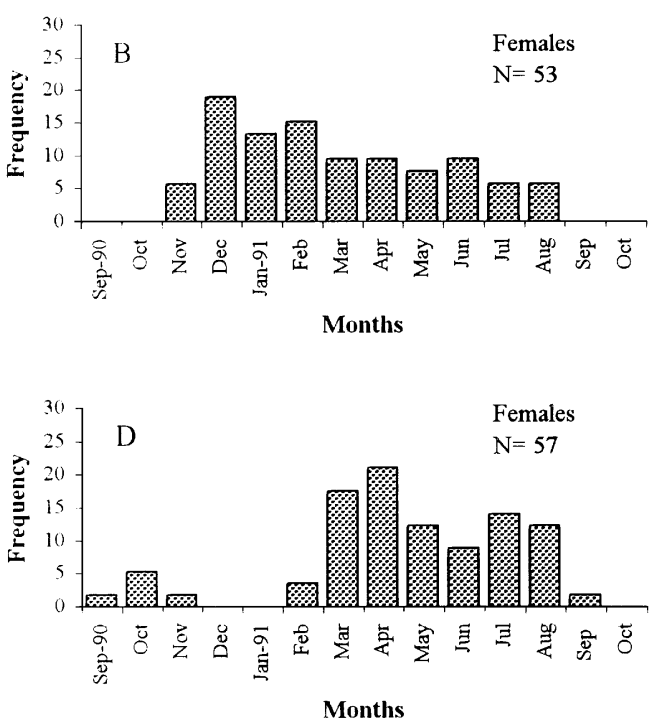

Figure 4. L.oligo vulgaris and L. forbesi. Distribution of hatching dates; (A) L. vulgaris males; (B) L. vulgaris females; (C) L. forbesi males; (D) L. forbesi females. Data were back-calculated from statolith increment counts and month of capture for both species and sexes. 

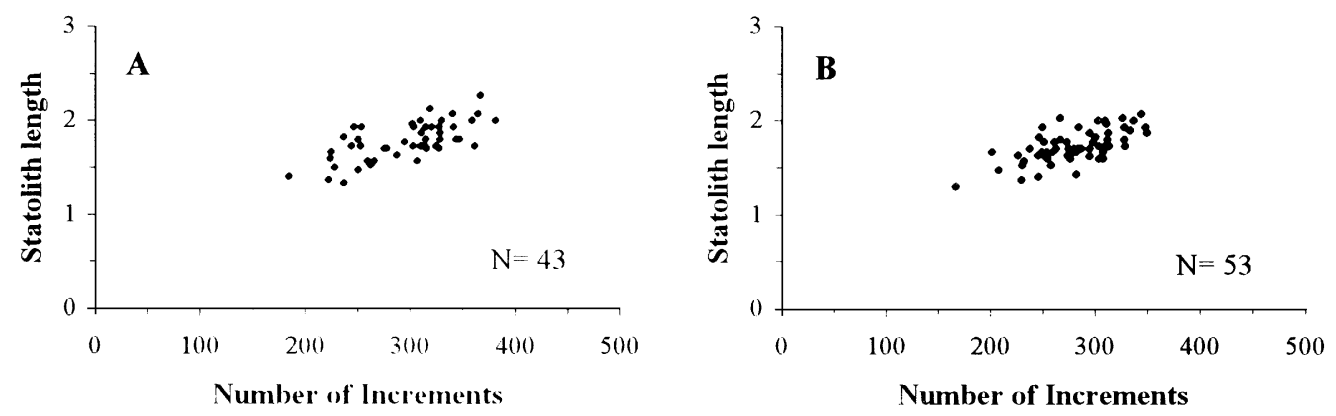

Figure 5. Loligo vulgaris: relationship between statolith length and number of increments of males (A) and females (B).
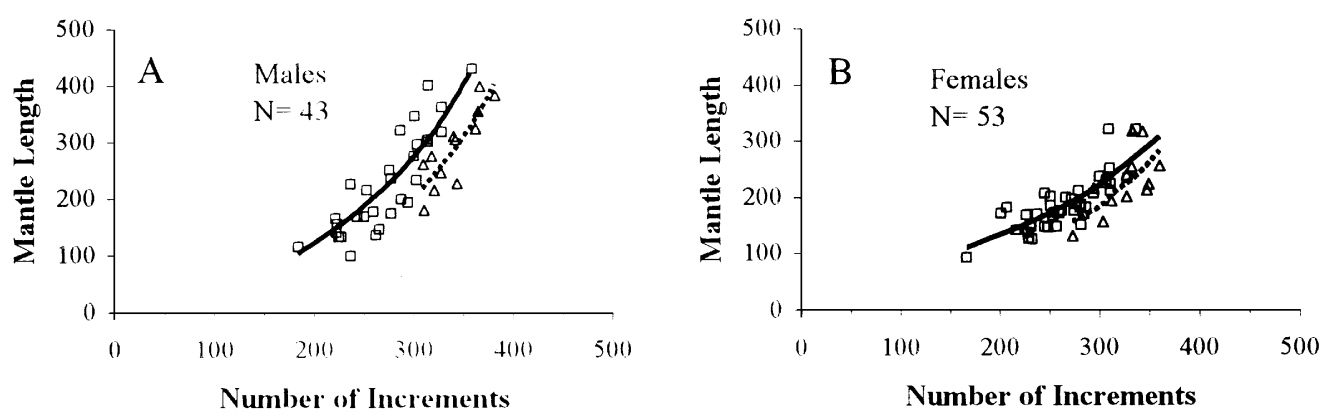

Figure 6. Loligo vulgaris: relationship between number of increments and mantle length in males (A) and females (B). Proposed growth curves for specimens hatched in summer-autumn $(\triangle)$ and winter-spring $(\square)$ seasons are illustrated.

Figure 8 shows the relationship between NI and ML in males and females hatched between December 1990July 1991. It can be observed that a considerable ML variation among individuals of same age was found.

According to their hatching date, males of $L$. forbesi can be separated into three groups: summer, autumn and winter/spring. In females, however, only two groups can be defined: summer-autumn and winter-spring groups (Figure 8). The growth functions that best fitted the data of both sexes were of three types: exponential in the case of males hatched in summer and winter-spring, linear for males hatched in autumn, and, finally, logarithmic in the case of both female groups. The parameters of these functions, DGR and G values are shown in Table 5 .

Considering the number of increments counted (Figure 8), the post-hatch life span of $L$. forbesi males and females should be about 18 months.

Significant sexual difference in growth was observed when comparing males and females of this species in all hatching seasons (Table 6). Significant differences were found between the growth of specimens hatched at different seasons for the same sex of this species (Table 6).

\section{Loligo vulgaris and Loligo forbesi growth comparison}

A comparison between sexes of both species (Table 7) showed that growth of $L$. forbesi males hatched in autumn was significantly faster than growth of $L$. vulgaris males hatched at any season of the year. However, no significant differences $(P>0.05)$ were found when comparing growth of $L$. vulgaris males with growth of $L$. forbesi males hatched in summer. Growth of males and females of both species hatched in other seasons was significantly different (Table 7). Growth functions parameters (Tables 3 and 5) suggest that small ( $<200 \mathrm{~mm} \mathrm{ML)} \mathrm{L.} \mathrm{forbesi} \mathrm{females} \mathrm{grew}$ faster than small $(<200 \mathrm{~mm} \mathrm{ML}) L$. vulgaris females, whilst the contrary seems to occur in larger females of both species.

The statolith analysis showed that two groups composed the exploited population of $L$. vulgaris in Galician waters: one formed by individuals hatched in winter-spring and

Table 3. Growth estimations using the exponential equation $\left(M L=a\left(e^{b N I}\right)\right)$ of Loligo vulgaris hatched in different seasons.

\begin{tabular}{|c|c|c|c|c|c|c|c|c|}
\hline \multicolumn{2}{|c|}{ Growth estimation } & \multirow{2}{*}{$\begin{array}{c}\mathrm{a} \\
16.176\end{array}$} & \multirow{2}{*}{$\frac{b}{0.0084}$} & \multirow{2}{*}{$\frac{r^{2}}{0.68}$} & \multirow{2}{*}{$\frac{\mathrm{N}}{12}$} & \multirow{2}{*}{$\begin{array}{l}\text { NI range } \\
300-382\end{array}$} & \multirow{2}{*}{$\begin{array}{c}\text { DGR } \\
0.54-3.04\end{array}$} & \multirow{2}{*}{$\frac{G}{0.84}$} \\
\hline Males & summer-autumn & & & & & & & \\
\hline & winter-spring & 21.14 & 0.0084 & 0.74 & 31 & $185-380$ & $0.71-3.98$ & 0.84 \\
\hline \multirow[t]{2}{*}{ Females } & summer-autumn & 24.278 & 0.0068 & 0.52 & 14 & $260-361$ & $0.51-2.05$ & 0.68 \\
\hline & winter-spring & 43.88 & 0.0053 & 0.67 & 39 & $167-350$ & $0.56-1.65$ & 0.53 \\
\hline
\end{tabular}

NI, number of increments; ML, mantle length (mm); a, intercept; b, slope; $r^{2}$, coefficient of determination; N, number of statoliths; NI range, range of increments used to estimate the equation; DGR, daily growth rate $\left(\mathrm{mm} \mathrm{d}^{-1}\right)$; G, instantaneous daily growth rate. 
Table 4. Comparisons between growth equations of Loligo vulgaris (slope and intercept) given in Table 3 using Student's test.

\begin{tabular}{|c|c|c|c|c|c|c|c|c|}
\hline \multirow[t]{2}{*}{ Comparison } & \multicolumn{4}{|c|}{ Slope } & \multicolumn{4}{|c|}{ Intercept } \\
\hline & $t$ & $v$ & $P$ & Prob. & $t$ & $v$ & $P$ & Prob. \\
\hline $\begin{array}{l}\text { Males } \\
\text { summer-autumn vs winter-spring }\end{array}$ & 0.0508 & 38 & $P>0.05$ & $\mathrm{~ns}$ & 0.2268 & 39 & $P>0.05$ & $\mathrm{~ns}$ \\
\hline $\begin{array}{l}\text { Females } \\
\text { summer-autumn vs winter-spring }\end{array}$ & 0.3653 & 49 & $P>0.05$ & ns & 0.3560 & 50 & $P>0.05$ & $\mathrm{~ns}$ \\
\hline $\begin{array}{l}\text { Males vs Females } \\
\text { summer-autumn vs summer-autumn } \\
\text { summer-autumn vs winter-spring } \\
\text { winter-spring vs winter-spring } \\
\text { winter-spring vs summer-autumn }\end{array}$ & $\begin{array}{l}2.7893 \\
3.9031 \\
3.4190 \\
2.5579\end{array}$ & $\begin{array}{l}22 \\
47 \\
65 \\
40\end{array}$ & $\begin{array}{l}P<0.02 \\
P<0.001 \\
P<0.002 \\
P<0.02\end{array}$ & $\begin{array}{l}* \\
* * \\
* * \\
*\end{array}$ & $\begin{array}{l}2.3954 \\
3.3001 \\
2.7692 \\
2.1414\end{array}$ & $\begin{array}{l}23 \\
48 \\
66 \\
41\end{array}$ & $\begin{array}{l}P<0.05 \\
P<0.002 \\
P<0.01 \\
P<0.05\end{array}$ & $\begin{array}{l}* \\
* * \\
* \\
*\end{array}$ \\
\hline
\end{tabular}

Prob., level of probability; *, significant differences; ns, no significant differences.
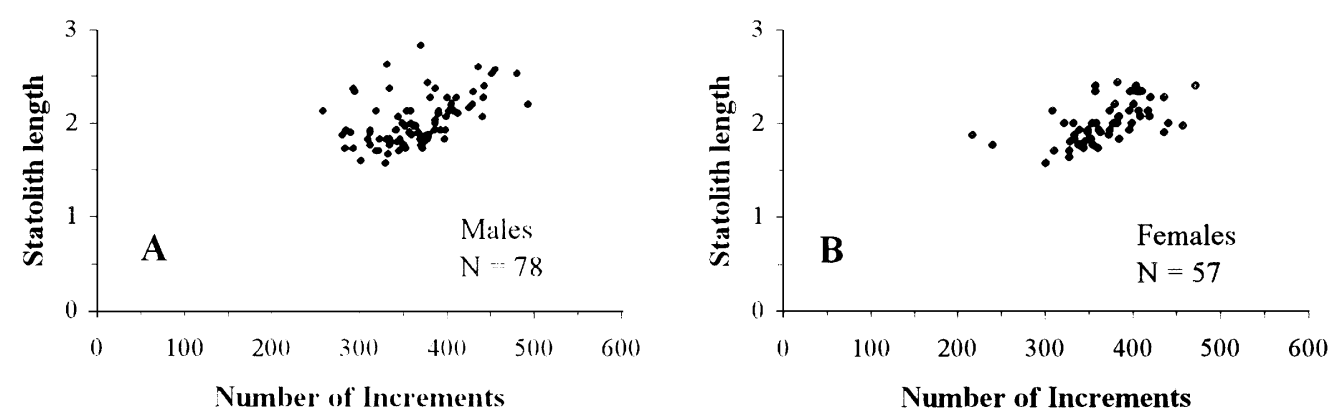

Figure 7. Loligo forbesi: relationship between statolith length and number of increments of males (A) and females (B).
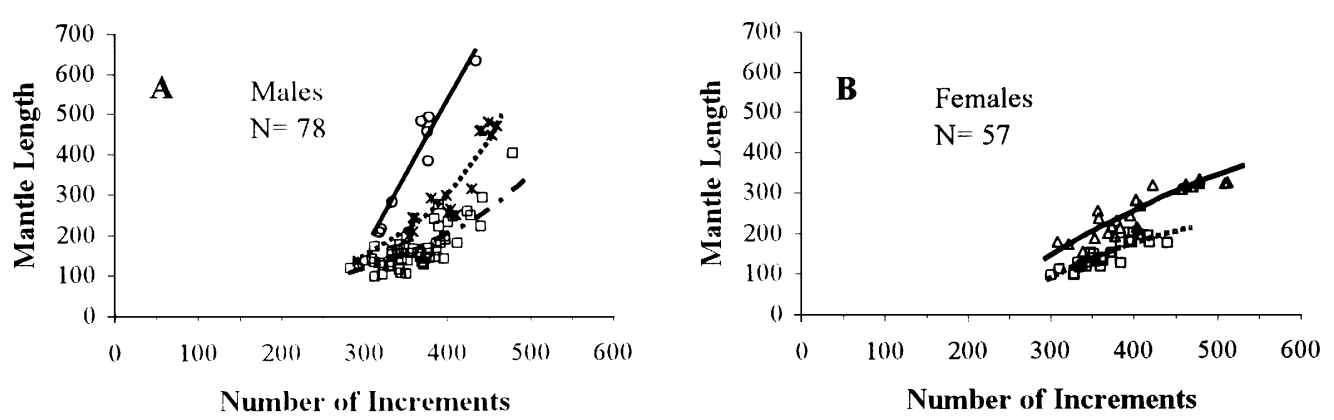

Figure 8. Loligo forbesi: relationship between number of increments and mantle length in males (A) and females (B). Proposed growth curves for males hatched in summer $(X)$, autumn $(O)$ and winter-spring $(\square)$ and for females hatched in summer-autumn $(\triangle)$ and winter-spring $(\square)$ seasons are shown.

Table 5. Growth estimations using the exponential $\left(M L=a\left(e^{b N I}\right)\right)$, logarithmic $(M L=a+b \ln (\mathcal{N} I))$ and linear $(M L=a+b$ $\mathcal{N I}$ ) equations for Loligo forbesi hatched at different seasons of the year.

\begin{tabular}{lllccrrrrr}
\hline Growth estimation & Equation & $\mathrm{a}$ & $\mathrm{b}$ & $r^{2}$ & $\mathrm{~N}$ & NI range & DGR & $\mathrm{G}$ \\
\hline \multirow{2}{*}{ Males } & summer & exponential & 14.92 & 0.0056 & 0.89 & 16 & $280-480$ & $0.41-1.13$ & 0.56 \\
& autumn & linear & -959.57 & 3.7079 & 0.92 & 8 & $310-450$ & 3.71 & $0.49-4.34$ \\
\multirow{2}{*}{ Females } & winter-spring & exponential & 20.503 & 0.0056 & 0.61 & 54 & $284-480$ & $0.57-1.55$ & 0.56 \\
& summer-autumn & logarithmic & -1977.9 & 371.43 & 0.81 & 27 & $305-514$ & $0.75-1.30$ & $0.23-1.09$ \\
& winter-spring & logarithmic & -1656.9 & 305.18 & 0.76 & 30 & $301-440$ & $0.62-1.07$ & $0.26-1.61$ \\
\hline
\end{tabular}

NI, number of increments; ML, mantle length (mm); a, intercept; b, slope; $r^{2}$, coefficient of determination; N, number of statoliths; NI range, range of increments used to estimate the equation; DGR, daily growth rate $\left(\mathrm{mm} \mathrm{d}^{-1}\right)$; $\mathrm{G}$, instantaneous daily growth rate. 
Table 6. Comparisons between growth equations of Loligo forbesi (slope and intercept) given in Table 5 using Student's test.

\begin{tabular}{|c|c|c|c|c|c|c|c|c|}
\hline \multirow[t]{2}{*}{ Comparison } & \multicolumn{4}{|c|}{ Slope } & \multicolumn{4}{|c|}{ Intercept } \\
\hline & $t$ & $v$ & $P$ & Prob. & $t$ & $v$ & $P$ & Prob. \\
\hline \multicolumn{9}{|l|}{ Males } \\
\hline summer vs winter-spring & 8.4835 & 66 & $P<0.001$ & $* *$ & 5.6689 & 67 & $P<0.001$ & $* *$ \\
\hline summer vs autumn & 2.7853 & 20 & $P<0.01$ & * & 2.3533 & 21 & $P<0.05$ & * \\
\hline autumn vs winter-spring & 10.9925 & 58 & $P<0.001$ & $* *$ & 6.0975 & 58 & $P<0.001$ & $* *$ \\
\hline $\begin{array}{l}\text { Females } \\
\text { summer-autumn vs winter-spring }\end{array}$ & 12.6618 & 53 & $P<0.001$ & $* *$ & 6.2500 & 54 & $P<0.001$ & $* *$ \\
\hline $\begin{array}{l}\text { Males vs Females } \\
\text { summer vs summer-autumn }\end{array}$ & 4.0649 & 39 & $P<0.001$ & ** & 3.1888 & 40 & $P<0.005$ & $* *$ \\
\hline summer vs winter-spring & 9.9331 & 42 & $P<0.001$ & $* *$ & 5.2545 & 43 & $P<0.001$ & $* *$ \\
\hline summer vs summer-autumn & 7.5540 & 31 & $P<0.001$ & $* *$ & 4.3314 & 32 & $P<0.001$ & $* *$ \\
\hline autumn vs winter-spring & 12.0885 & 34 & $P<0.001$ & $* *$ & 5.1374 & 35 & $P<0.001$ & $* *$ \\
\hline winter-spring vs summer-autumn & 6.6803 & 77 & $P<0.001$ & $* *$ & 5.3330 & 78 & $P<0.001$ & $* *$ \\
\hline winter-spring vs winter-spring & 3.2271 & 80 & $P<0.002$ & $* *$ & 2.8968 & 81 & $P<0.005$ & $* *$ \\
\hline
\end{tabular}

Prob., level of probability; *, significant differences; ns, no significant differences.

Table 7. Comparisons of growth equations between Loligo vulgaris and Loligo forbesi (slope and intercept) given in Tables 3 छ 5 using Student's test.

\begin{tabular}{|c|c|c|c|c|c|c|c|c|}
\hline \multirow{2}{*}{$\begin{array}{l}\text { Comparison } \\
\text { Loligo vulgaris vs Loligo forbesi }\end{array}$} & \multicolumn{4}{|c|}{ Slope } & \multicolumn{4}{|c|}{ Intercept } \\
\hline & $t$ & $v$ & $P$ & Prob. & $t$ & $v$ & $P$ & Prob. \\
\hline \multicolumn{9}{|l|}{ Males } \\
\hline summer-autumn vs summer & 0.7732 & 24 & $P>0.05$ & $\mathrm{~ns}$ & 0.9375 & 25 & $P>0.05$ & $\mathrm{~ns}$ \\
\hline summer-autumn vs autumn & 2.2594 & 16 & $P<0.05$ & $*$ & 1.8549 & 17 & $P>0.05$ & $\mathrm{~ns}$ \\
\hline summer-autumn vs winter-spring & 9.3731 & 62 & $P<0.001$ & $* *$ & 6.0657 & 63 & $P<0.001$ & $* *$ \\
\hline winter-spring vs summer & 0.8598 & 42 & $P>0.05$ & $\mathrm{~ns}$ & 0.8656 & 43 & $P>0.05$ & $\mathrm{~ns}$ \\
\hline winter-spring vs autumn & 2.7699 & 34 & $P<0.01$ & $*$ & 2.3844 & 35 & $P<0.05$ & $*$ \\
\hline winter-spring vs winter-spring & 9.9083 & 80 & $P<0.001$ & $* *$ & 6.3114 & 81 & $P<0.001$ & $* *$ \\
\hline \multicolumn{9}{|l|}{ Females } \\
\hline summer-autumn vs summer-autumn & 2.0422 & 37 & $P<0.05$ & $*$ & 1.9896 & 38 & $P>0.05$ & ns \\
\hline summer-autumn vs winter-spring & 10.0132 & 40 & $P<0.001$ & $* *$ & 5.3766 & 41 & $P<0.001$ & $* *$ \\
\hline winter-spring vs summer-autumn & 3.5347 & 62 & $P<0.001$ & $* *$ & 3.1500 & 63 & $P<0.005$ & $* *$ \\
\hline winter-spring vs winter-spring & 14.5383 & 65 & $P<0.001$ & $* *$ & 6.8709 & 66 & $P<0.001$ & $* *$ \\
\hline
\end{tabular}

Prob., level of probability; *, significant differences; ns, no significant differences.

another by specimens hatched in summer-autumn. Those hatched in the first period attained larger sizes at the same age than those hatched in the second period.

These two groups were also observed in the exploited population of L. forbesi. However, L. forbesi born in winterspring were smaller than those hatched in summerautumn at the same age. Moreover, males hatched in autumn showed the largest sizes at any age in the fishery.

\section{DISCUSSION}

Growth increments within the statolith microstructure of Loligo vulgaris and L. forbesi are similar to the increments in $L$. vulgaris from the West Saharan Shelf (Arkhipkin, 1995) and in L. forbesi from Irish waters (Collins et al., 1995a). It seems that the growth increment pattern observed is quite constant in loliginid species.
Thus, similar increments were found in L. opalescens (Hixon \& Villoch, 1983); Photololigo edulis (Natsukari et al., 1988), L. bleekeri (Kinoshita, 1989) and Sepioteuthis lessoniana (Jackson, 1990). The nucleus of both species studied in this paper showed a droplet-like form and was constituted by several tiny primordia as observed by Arkhipkin (1995) in L. vulgaris from west African waters. The natal ring of $L$. vulgaris and $L$. forbesi from north-west Spain was identified as described in $L$. vulgaris from the western Mediterranean (Natsukari \& Komine, 1992). As pointed out by Natsukari et al. (1993), it was considered that estimating age from only the number of thick, dark rings observed was very risky. Accordingly we counted both types of increments found in our prepared statoliths: those formed by a fine ring and a translucent layer and the increments constituted by a dark ring and a translucent layer. 
The statoliths of $L$. forbesi are larger than the statoliths of $L$. vulgaris. Statoliths length of $L$. forbesi varying from $2.2 \% \mathrm{ML}$ in juveniles of $70 \mathrm{~mm} \mathrm{ML}$ to $0.41 \% \mathrm{ML}$ in mature males of $685 \mathrm{~mm} \mathrm{ML}$, and from $1.7 \% \mathrm{ML}$ in juveniles $70 \mathrm{~mm} \mathrm{ML}$ to $0.45 \% \mathrm{ML}$ in mature $L$. vulgaris males of $480 \mathrm{~mm}$ ML. Arkhipkin (1995) found a similar statolith length range in L. vulgaris from the Saharan shelf. The growth in length of the statolith decreases gradually with individual growth in both species. This pattern was also found in other loliginid species as Alloteuthis subulata and A. africana (Arkhipkin \& Nekludova, 1993), but in L. vulgaris and L. forbesi the allometric coefficient (b) was approximately 2.5 times larger than that of both Alloteuthis spp., reflecting faster allometric growth of $L$ vulgaris and $L$. forbesi statoliths. Bettencourt et al. (1996) also found that the statolith of L. vulgaris from the south coast of Portugal decreased gradually with individual growth. These authors indicated that this result might be related to the onset of sexual maturation as described in other cephalopods.

A hatching period occurring throughout the year in both species was also observed in other geographical areas (Natsukari \& Komine, 1992; Arkhipkin, 1995; Collins et al., 1995a,b; Bettencourt et al., 1996). Although main and secondary peaks of hatching were observed in both species, the method of using the statolith data to evaluate hatching date is not without its problems. Most notably the seasonal variation of squid abundance at the time of capture is not taken into account (Collins et al., 1997). The fact that our results indicate some sex specific peaks in hatching could be caused by different migration patterns, causing only one of the sexes to be sampled. Segregation of sexes at different depths and asynchronic migration of sexes were deduced from observation by Mangold-Wirz (1963) and Worms (1983) in L. vulgaris from the western Mediterranean. However, further research is necessary in order to clarify that migratory pattern.

The great variation in individual growth rates in L. vulgaris and $L$. forbesi found in the present study agrees with that observed in wild populations of these species by other authors. Thus, Natsukari \& Komine (1992), Arkhipkin, (1995) and Bettencourt et al. (1996) found that L. vulgaris specimens of the same length could have variations of 150 increments. Collins et al. (1995a) observed variations of 200 increments for L. forbesi individuals of the same length. Such variability has also been reported in laboratory cultured $L$. vulgaris and L. forbesi (Turk et al., 1986; Hanlon et al., 1989). Considerable variations in individual growth rates were also observed in other loliginid squid, e.g. Alloteuthis subulata, Photololigo edulis, Heterololigo bleekeri and Loligo gahi (Lipinski, 1986; Natsukari et al., 1988; Kinoshita, 1989; Hatfield, 1991). Considerable variation in individual growth rate is probably a common character in all loliginids as shown by these previous findings along with the results in this study. This high variability in individual growth rates could be associated with temperature, food availability and the individual size at maturation (Forsythe \& Van Heukelen, 1987; Rodhouse \& Hatfield, 1990; Bettencourt et al., 1996).

Sexual dimorphism observed in both species, with males growing faster and attaining larger sizes than females, is common amongst loliginid squid (see reviews in Boyle, 1983; Natsukari \& Komine, 1992; Arkhipkin, 1995; Collins et al., 1995a).

The results obtained from statolith analysis in both species suggest the existence of two different lifestyles. L. vulgaris seems to be a species closely related with coastal waters throughout its life cycle. The individuals of this species hatched in winter-spring in shallow waters (Guerra \& Rocha, 1994) should have high growth rates during early stages of development in summer and autumn when environmental conditions are more favourable. This is mainly due to the presence of a coastal summer-autumn upwelling that notably increases the productivity of Galician waters (Fraga, 1981; Blanton et al., 1984; Rocha et al., 1999). On the contrary, squid hatched in summer-autumn would find unfavourable environmental conditions when pre-recruit, which should account for lower growth rates than those hatched in winter-spring. Moreover, L. forbesi seems to be a more oceanic species than $L$. vulgaris, carrying out relatively long offshore displacements throughout its life cycle. The individuals of this species hatched inshore in winterspring are found offshore in summer-autumn. Therefore, they would not benefit from the favourable conditions prevailing in coastal waters during upwelling. This would account for their relatively low growth rates. An inshore displacement of these individuals seems to occur when they start to mature. The small maturing animals would reach coastal waters in winter-spring. On the other hand, the specimens hatched inshore in summer would arrive at offshore areas, larger than the individuals hatched in winter-spring. This can be induced by the high food availability during upwelling. These squid would return to coastal waters in summer when upwelling is strongest but when fish populations, that constitute their main prey (Rocha et al., 1994), are still not very abundant. However, individuals hatched in autumn would return to coastal waters later than those hatched in summer, when fish populations are abundant in coastal waters. This increase in food availability might account for their high growth rates. Therefore, squid hatched in autumn would have larger sizes than the summer ones at the same age. The difference in size at the same age observed between males and females hatched in autumn could be explained because females diverted more energy from somatic growth to gonad production than males (Collins et al., 1995a).

Daily growth rate (DGR) and instantaneous growth rate $(\mathrm{G})$ of $L$. vulgaris obtained in the present paper agree with those estimated from the wild (Natsukari \& Komine, 1992; Arkhipkin, 1995; Bettencourt et al., 1996), and from laboratory reared specimens (Turk et al., 1986). Moreover, instantaneous growth rate differences observed between $L$. forbesi males and females hatched in autumn agree with those reported by Collins et al. (1995a). It can also be observed that $\mathrm{G}$ values estimated by these authors agree with those obtained in the present study for males and females hatched in other seasons.

No evidence was found that either male or female L. vulgaris live longer than one year. This agrees with the results obtained using statolith analysis in other regions (Natsukari \& Komine, 1992; Arkhipkin, 1995; Bettencourt et al., 1996). Large L. forbesi males and females live 18 months in Galician waters. This disagrees with the 
observations of Collins et al. (1995a) in Irish waters, where a one-year life cycle was postulated. However, this could agree with Martins' observations (1982) in specimens from the Azores. The discrepancy between Collins et al. (1995a) and our findings could be due to the fact that the maximum size of $L$. forbesi never surpassed $505 \mathrm{~mm}$ ML in Irish waters, whereas larger animals are relatively common in Galicia and the Azores (Guerra \& Rocha, 1994; Porteiro \& Martins, 1994). Nevertheless, these differences might also reflect the different methods and zones employed in statolith increment reading, to the natal ring toward the dorsal dome by Collins et al. (1995a) and toward the rostrum in the present study. Thus, it would be possible that in the larger males the increments become highly compressed in the dorsal dome but more easily resolved in the rostrum.

We thank V. Bettencourt, B.G. Castro, E.G. Dawe, A.F. González, P. Martínez, G.J. Pierce and M. Rasero for their useful comments on earlier drafts of this manuscript. Also, to the anonymous reviewers for their criticism and helpful suggestions. This research was supported by two projects under the auspices of the European Union (FAR, M.A. 1.146 and AIR 1-CT92-0573).

\section{REFERENCES}

Arkhipkin, A.I., 1991. Method for cephalopod age and growth studies with emphasis on statolith ageing techniques. In Squid age determination using statoliths. Proceedings of the International Workshop held in the Istituto di Tecnologia delle Pesca e del Pescato, Italy (ed. P. Jereb et al.), pp.11-17. Special publication, no. 1, 127 pp.

Arkhipkin, A.I., 1995. Age, growth and maturation of the European squid Loligo vulgaris (Myopsida, Loliginidae) on the West Saharan shelf. Fournal of the Marine Biological Association of the United Kingdom, 75, 593-604.

Arkhipkin, A.I. \& Nekludova, N., 1993. Age, growth and maturation of the loliginid squids, Alloteuthis africana and A. subulata on the West African shelf. Fournal of the Marine Biological Association of the United Kingdom, 73, 949-961.

Bettencourt, V., Coelho, M.L., Andrade, J.P. \& Guerra, A. 1996. Age and growth of Loligo vulgaris of south of Portugal by statolith analysis. Fournal of Molluscan Studies, 62, 359-366.

Blanton, J.O., Atkinson, L.P., Fernández de Castillejo, F. \& Lavín, A., 1984. Coastal upwelling off the Rias Bajas, Galicia. Northwest Spain I: Hydrographic studies. Rapports et Procèsverbaux des Réunions. Conseil International pour l'Exploration de la Mer. Copenhague, 183, 79-90.

Boyle, P.R., 1983. Cephalopod Life Cycles. Vol. 1. Species Accounts. London: Academic Press.

Boyle, P.R. \& Ngoile, M.A.K., 1993. Assessment of maturity state and seasonality of reproduction in Loligo forbesi (Cephalopoda: Loliginidae) from Scottish waters. In Recent advances in fisheries biology (ed. T. Okutani et al.), pp. 37-48. Tokyo: Tokai University Press.

Clarke, M.R., 1978. The cephalopod statolith - an introduction to its form. Fournal of the Marine Biological Association of the United Kingdom, 58, 701-712.

Collins, M.A., Burnell, G.M. \& Rodhouse, P.G., 1995a. Age and growth of the squid Loligo forbesi (Cephalopoda: Loliginidae) in Irish waters. Fournal of the Marine Biological Association of the United Kingdom, 75, 605-620.

Collins M.A., Burnell, G.M. \& Rodhouse, P.G., 1995b. Recruitment, maturation, and spawning of Loligo forbesi Steenstrup (Cephalopoda: Loliginidae) in Irish waters. ICES Journal of Marine Science, 52, 127-137.
Collins, M.A., Pierce, G.J. \& Boyle, P.R., 1997. Population indices of reproduction and recruitment in Loligo forbesi (Cephalopoda: Loliginidae) in Scottish and Irish waters. Fournal of Applied Ecology, 34, 778-786.

FAO, 1997. Catches and landings. In FAO Yearbook of Fishery Statistics, vol. 80. Rome: FAO.

Forsythe, J.W., 1993. A working hypothesis how seasonal temperature change may impact the field growth of young cephalopods. In Recent advances in fisheries biology (ed. T. Okutani et al.), pp. 133-143. Tokyo: Tokai University Press.

Forsythe, J.W. \& Van Heukelem, W.F., 1987. Growth. In Cephalopod life cycles. Vol. 2. Comparative reviewes (ed. P.R. Boyle), pp. 135-156. London: Academic Press.

Fraga, F., 1981. Upwelling off the Galician coast, Northwest Spain. In Coastal upwelling (ed. F.A. Richards), pp. 176-182. Washington, DC: American Geophysical Union.

González, A.F., Macy, W.K. \& Guerra, A., 1998. Validation of a semi-automatic image analysis system to age squids and its application to age Illex coindetii statoliths. ICES fournal of Marine Science, 55, 535-544.

Guerra, A. \& Rocha, F., 1994. The life history of Loligo vulgaris and Loligo forbesi (Cephalopoda: Loliginidae) in Galician waters (NW Spain). Fisheries Research, 21, 43-69.

Hanlon, R.T., Yang, W.T., Turk, P.E., Lee, P.G. \& Hixon, R.F., 1989. Laboratory culture and estimated life span of the eastern Atlantic squid, Loligo forbesi Steenstrup, 1856 (Mollusca: Cephalopoda). Aquaculture and Fisheries Management, 20, 15-34.

Hatfield, E.M.G., 1991. Post-recruit growth of the Patagonian squid Loligo gahi (D’Orbigny). Bulletin of Marine Science, 49, 349-361.

Hixon, R.F. \& Villoch, M.R., 1983. Growth rings in the statoliths of young laboratory cultured squid (Loligo opalescens). American Malacological Bulletin, 2, 93.

Jackson, G.D., 1990. Age and growth of the tropical nearshore loliginid squid Sepioteuthis lessoniana determined from statolith growth-ring analysis. Fishery Bulletin. National Oceanic and Atmospheric Administration. Washington, DC, 88, 113-118.

Jackson, G.D., 1994. Application and future potential of statolith increment analysis in squids and sepioids. Canadian Fournal of Fisheries and Aquatic Sciences, 51, 2612-2625.

Kinoshita, T., 1989. Age and growth of loliginid squid, Heterololigo bleekeri. Bulletin Seikai Regional Fishery Research Laboratory, 67, 59-68.

Lipinski, M.R., 1986. Methods for the validation of squid age from statoliths. Fournal of the Marine Biological Association of the United Kingdom, 66, 505-526.

Lipinski, M.R., Dawe, E. \& Natsukari, Y., 1991. Introduction. In Squid age determination using statoliths. Procceedings of the International Workshop held in the Istituto di Tecnologia delle Pesca e del Pescato, Italy (ed. P. Jereb et al.), pp. 77-81. Special publication, no. 1, 127 pp.

Mangold-Wirz, K., 1963. Biologie des céphalopodes bentiques et nectoniques de la Mer Catalane. Vie et Milieu, 13 (Supplement), $1-285$.

Martins, H.R., 1982. Biological studies of the exploited stock of Loligo forbesi (Mollusca: Cephalopoda) in the Azores. Fournal of the Marine Biological Association of the United Kingdom, 62, 799-808.

Natsukari, Y. \& Komine, N., 1992. Age and growth estimation of the European squid, Loligo vulgaris, based on statolith microstructure. Fournal of the Marine Biological Association of the United Kingdom, 72, 271-280.

Natsukari, Y., Mukai, H., Nakahama, S. \& Kubodera, T., 1993. Age and growth estimation of a gonatid squid Berryteuthis magister, based on statolith microstructure (Cephalopoda: Gonatidae). In Recent advances in fisheries biology (ed. T. Okutani et al.), pp. 351-364. Tokyo: Tokai University Press.

Natsukari, Y., Nakanose, T. \& Oda, K., 1988. Age and growth of loliginid Photololigo edulis (Hoyle, 1885). Fournal of Experimental Marine Biology and Ecology, 116, 177-190. 
Peréz-Losada, M., 1998. Diferenciación genética y filogenia de Sepia spp. y de otras diez especies de cefalópodos de las familias Ommastrephidae, Loliginidae, Sepiolidae y Octopodidae. PhD Thesis, University of Vigo, Vigo, Spain.

Pierce, G.J. \& Guerra, A., 1994. Stock assessment methods used for cephalopod fisheries. Fisheries Research, 21, 255-285.

Porteiro, F.M. \& Martins, H.R., 1994. Biology of Loligo forbesi Steenstrup, 1856 (Mollusca: Cephalopoda) in the Azores: sample composition and maturation of squid caught by jigging. Fisheries Research, 21, 103-114.

Rocha, F., Gastro, B.G., Gil, M.S. \& Guerra, A., 1994. The diets of Loligo vulgaris and L. forbesi (Cephalopoda: Loliginidae) in northwestern Spanish Atlantic waters. Sarsia, 79, 119-126.

Rocha, F., Guerra, A., Prego, R. \& Piatkowski, U., 1999. Cephalopod paralarvae and upwelling conditions off Galician waters (NW Spain). Journal of Plankton Research, 21, 21-33.

Rodhouse P.G. \& Hatfield, E.M.G., 1990. Age determination in squid using statolith growth increments. Fisheries Research, 8, 323-334.
Simón, F., Rocha, F. \& Guerra, A., 1996. The small-scale squid hand-jig fishery off the northwestern Iberian Peninsula: application of a model based on a short survey of fishery statistics. Fisheries Research, 25, 253-263.

Turk, P.E., Hanlon, R.T., Bradford, L.A. \& Yang, W.T., 1986. Aspects of feeding, growth and survival of the European squid Loligo vulgaris Lamarck 1799, reared through the early growth stages. Vie et Milieu, 36, 9-13.

Villanueva, R., 1992. Interannual growth differences in the oceanic squid Todarodes angolensis Adam in the northern Benguela upwelling system, based on statoliths growth increment analysis. Fournal of Experimental Marine Biology and Ecology, 159, 157-177.

Worms, J., 1983. Loligo vulgaris. In Cephalopod Life Cycles. Vol. 1. Species Accounts (ed. P.R. Boyle), pp. 143-157. London: Academic Press.

Zar, J.H., 1984. Biostatistical analysis, 2nd ed. Englewood Cliffs, New Jersey: Prentice Hall.

Submitted 13 November 1997. Accepted 28 October 1998. 